'Discretionary disclosures: reactivity and proactivity in the chairpersons' statements of JSE-listed companies in South Africa"

AUTHORS Nthabeleng Mmako

Nthabeleng Mmako (2016). Discretionary disclosures: reactivity and proactivity in

ARTICLE INFO the chairpersons' statements of JSE-listed companies in South Africa. Problems and Perspectives in Management, 14(3-2), 512-521. doi:10.21511/ppm.14(32).2016.07

DOI http://dx.doi.org/10.21511/ppm.14(3-2).2016.07

RELEASED ON Tuesday, 27 September 2016

JOURNAL

"Problems and Perspectives in Management"

FOUNDER

LLC "Consulting Publishing Company "Business Perspectives"

NUMBER OF REFERENCES

0

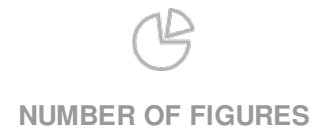

0

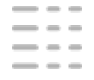

NUMBER OF TABLES

0

(C) The author(s) 2022. This publication is an open access article. 
Nthabeleng Mmako (South Africa)

\title{
Discretionary disclosures: reactivity and proactivity in the chairpersons' statements of JSE-listed companies in South Africa
}

\begin{abstract}
A review of the literature on corporate governance and narrative disclosures highlights the need for assessment of the formulation of the chairperson's statement. This research is justified as corporate reporting today is more integrated. The significance of the study may be that even though only the chairperson's statement is investigated, it may be a good starting point for understanding how change is ushered into an organization and from what perspective this takes place. Findings of content analysis of 100 Johannesburg Stock Exchange (JSE)-listed chairperson's statements suggest that as part of the communication intended mainly for investors and other stakeholders of the company, the chairperson's statement is written as a reactive statement to environmental factors or as a proactive statement to counter environmental factors that may affect or have affected the company's performance. This study will be useful in helping readers to improve their understanding of a company's efforts to communicate with them, from the chairperson's perspective.
\end{abstract}

Keywords: chairperson's statement, JSE, disclosures, reactivity, proactivity.

JEL Classification: G3, G30.

\section{Introduction}

As a requirement of the Companies Act of 2008, all publicly listed companies in South Africa are required to produce integrated annual reports within six months of their financial year-end. Often contained in this integrated annual report is the customary statement of the chairperson. Written by the highest order of the board, the chairperson's statement provides insight into the organization's reality through an explanation of its performance and insight into its strategic plan. The chairperson's statement is associated with the future of the company and such unaudited disclosures contain important information which is not only concerned with a report of the company's past performance (Riley \& Luippold, 2015, p. 61; Smith \& Taffler, 2000, p. 625). The chairperson's statement generally provides valuable, but often overlooked information and implicit beliefs about the company's relationship with its environment.

However, there are many factors that could possibly influence a company's decision to disclose. These factors include the extent, frequency and method of disclosure; the company's objectives with disclosure; the size of the company, listing status, culture and complexity of the company; the size, type and culture of the company's shareholders; the cost of disclosure; the favorableness of the news; and the intensity of competition, earnings margins and rate of return (Myburgh, 2001, p. 201).

The formalization of reporting requirements, such as corporate governance, environmental disclosures and sector-specific issues, has made the discussion of certain pertinent issues necessary for

(C) Nthabeleng Mmako, 2016.

Nthabeleng Mmako, PhD Student, Lecturer, Department of Entrepreneurship, Supply Chain, Transport, Tourism and Logistics Management, University of South Africa, South Africa. inclusion in the chairperson's statement. From the chairperson's perspective, the inclusion of these issues in the chairperson's statement may be seen as a display of sincere effort to demonstrate accountability. From the reader's perspective, the inclusion of such issues may be seen as a way to judge the legitimacy of the organization.

Generally, corporate annual documents are seen as either reactive or proactive. These documents are considered proactive if they construct and project a particular image and are considered reactive if they respond to the concerns of particular groups (Stanton \& Stanton, 2002, p. 493). Awareness of reactivity and proactivity in the chairperson's statements of listed companies may contribute to an understanding of the priorities of the chairpersons of these listed companies regarding communication with various stakeholder groups.

The conceptual framework discussed in the literature review provides a starting point for the perspective from which the chairperson's statement is formulated.

\section{Purpose of the article}

By nature, financial statements are historical documents which indicate compliance and contain mandatory disclosures (Smith \& Taffler, 2000, p. 625; Abrahamson \& Amir, 1996, p. 1157). The unstructured nature of the chairperson's statement may be indicative of the intended communication strategy pursued by the organization with its stakeholder groups. Today, however, the chairperson's statement cannot be seen as merely a free-flow document guided primarily by what the chairperson would like to disclose to the public. Stakeholder concerns that inform whether a company's internal controls for performance involve the balance of interest of affected stakeholder groups should be addressed. This is important, since the importance of this statement as a 
contributing factor to an investment decision cannot be ignored (Abrahamson \& Amir, 1996, p. 1158; Kohut $\&$ Segars, 1992, p. 8). The purpose of this article is to describe reactive and proactive discretionary disclosures contained in the chairperson's statements of 50 high-performing and 50 poor-performing companies listed on the JSE. With the mandatory requirement of JSE-listed companies to produce integrated reports, this study will determine whether high-performing companies employ pre-emptive, hands-on communication tactics in their chairperson's statements, and if poor-performing companies employ combative and responsive communication tactics in their chairperson's statements. This is based on the general assumption in literature (Abrahamson \& Park, 1994; Bournois \& Point, 2006; Stanton \& Stanton, 2002) that good performance of the high-performing company is attributed to hands-on, sound strategic direction offered by the board and poor performance is a result of economic climate.

The remainder of the article addresses corporate governance in South Africa, followed by a discussion of discretionary disclosures. A conceptual framework that informed analysis is provided. The methodology used in the study is, then, explained, followed by a discussion of the findings and results. The article is concluded with a discussion of recommendations and implications.

\section{Literature review}

2.1. Corporate governance in South Africa. The heightened need for corporate governance reforms after global scandals such as Enron, WorldCom, Tyco and many others contributed significantly to the loss of investor confidence in annual reports. Boards were accused of not fulfilling their fiduciary responsibility to stakeholders. With the country's own corporate failures such as Fidentia, JCI-Randgold, Masterbond, Leisurenet, MacMed and Regal Treasury Bank (Mangena \& Chamisa, 2008, p. 29), corporate governance in South Africa is an issue that to date still generates interest in reporting documents.

Corporate governance reform in South Africa began with the release of the King I Report on Corporate Governance published in 1994. The release of the King I Report coincided with the demise of apartheid and the newly found democracy of the country.

The King II Report is notable for the introduction of 'triple-bottom-line' reporting in South Africa. For companies, this entailed reporting not only on the economic and financial bottom-line activities of the company, but also reporting on the social aspects and the impact of company activities on the environment in which the company operates (Andreasson, 2009, p. 659; West, 2009, p. 12).
Ioannou and Serafeim (2016, p. 9) add that although both King I and King II discussed sustainability issues as part of how boards manage companies, it was in the King III where ideas of leadership, sustainability, and corporate citizenship were emphasized to a great extent. Where financial statements report on the previous financial year, the integrative reporting prescribed by the King III Report should also provide forward-looking information and shed more light on sustainability efforts of the company.

The need for the King III Report on Corporate Governance was necessitated by the new Companies Act No. 71 of 2008 (Institute of Directors Southern Africa [IOD], 2009, p. 4). South Africa opted for the code of principles on the 'comply-and-explain' basis and following the King II report, the JSE required listed companies to provide a narrative statement detailing how the company had complied with the principles set out in the King II Report.

The JSE requires listed companies to comply with corporate governance standards, as set out in the King III Code of Corporate Governance. The narrative and non-narrative disclosures of companies have to provide a holistic representation of a company that is honest and verifiable. This representation must not only be a true reflection of the current financial position of the company, but also display commitment to the integrity of the organisation.

2.2. Voluntary disclosures. Researchers in the field of accounting have in the past recognized the urgent need to develop disclosure metrics to facilitate research into voluntary disclosures and the quality thereof (Beattie, McInnes \& Fearnley, 2004, p. 205). Even though incremental developments and measures have been put in place, no standardization or codes of best practices have been developed for narrative and voluntary disclosures. This task is still often left to the discretion of company executives. Depoers (2000, p. 245) qualifies disclosures as voluntary whenever the information that is provided goes beyond the compulsory information for shareholders.

A study by Padia and Yaseen (2011) found that, in South Africa, companies generally disclosed more on their corporate strategies, but there was a tendency to make sufficient disclosures to appease stakeholders without putting the company in jeopardy. This was attributed to the fact that strategy disclosure was voluntary and not mandatory. Companies were reluctant to disclose too much in fear of being held accountable for these 'promises'. In contrast, ethical, social and environmental information appeared more throughout annual reports than was previous practice in South Africa, which was to merely mention it in the chairperson's statement (Solomon \& Maroun, 2012, p. 5). However, reports showed that reporting on 
social, environmental and ethical issues is still driven largely by regulatory requirements. In their research, Solomon and Maroun $(2012$, p. 46) noted a change in discourse in the chairperson's statement which had become more stakeholder oriented. Overall, recent annual reports included lengthy discussions about the 'belief' in long-term stakeholder relationships, the creation of long-term value and wealth creation.

Myburgh (2001, p. 201) distinguishes between mandatory and voluntary disclosures, stating that mandatory disclosures are those that are required by law, stock exchanges and prescribers of accounting standards, whereas voluntary disclosures are made available at the discretion of the company. Yeoh (2010, p. 218) argues that the usefulness of mandatory disclosures as powerful deterrents against agency conflicts lies in their ability to address stakeholder concerns such as a company's social, safety and environmental impact. However, voluntary disclosures are described as biased with the problem of selective dissemination and what may be deemed 'creative accounting'. While it is assumed that a company can withhold information, any disclosure it makes must be truthful. This representation seems inaccurate in describing voluntary disclosures which are rarely auditable or verifiable (Stocken, 2012, p. 398). Stocken $(2012$, p. 399) explains this by stating that managers incur fixed costs in disclosing private information and this serves as friction; therefore, ruling out the possibility of a full disclosure. Verrecchia (1983, p. 179) concedes this position by referring to a threshold where an author exercises discretion by choosing a point or degree of the information quality above which he discloses what he observes, and below which he withholds information.

The disclosure of voluntary information is often justified from an economic standpoint where advantages to disclose must outweigh disadvantages to not disclose. This is often measured in terms of costs and the size of the risk to disclose (Depoers, 2000, p. 248).

2.2.1. Motivators for disclosure. Merkl-Davies and Brennan (2007, p. 167) provide two explanations for discretionary narrative disclosures. Firstly, they posit that discretionary narrative disclosures assist in informing better decision-making, as they provide incremental information that reduces information asymmetries between management and the company's stakeholders. Secondly, discretionary narrative disclosures provide the opportunity for company management or executives to exploit information through engaging in impression management.

While the explanations provided by Merkl-Davies and Brennan (2007) provide summative explanations for discretionary disclosures, Healy and Palepu (2001, pp. 420-424) discuss six factors that affect organizational disclosure decisions. These are listed as:

- Capital market transactions: Managers of a company can reduce the cost of capital through the reduction of information risk. This is possible through increased voluntary disclosure.

- Corporate control contests: Motivation for corporate control stems from the belief that investors hold managers accountable for stock performance.

- Stock compensation: Various types of compensation schemes given to managers provide incentives for managers to engage in voluntary disclosures.

- Litigation: Firstly, possible legal action against managers of companies for untimely or inadequate disclosures may increase voluntary disclosures. Secondly, litigation may reduce the incentive for managers to provide forward-looking information.

- Proprietary costs: Firms have an incentive to not disclose information that may jeopardize their competitive position.

- Management talent signalling: Trueman (in Healy \& Palepu, 2001, p. 424) argues that talented managers have an incentive to reveal future earnings as a means to reveal talent and to forecast ability.

2.3. Discretionary disclosure difficulties. Leventis and Weetman (2004, p. 308) maintain that when companies have enough freedom within the legislative framework of their specific country, they will experiment with accounting practices and the presentation thereof. Cheng and Courtenay (2006, p. 263) argue that since voluntary disclosures are subject to managerial discretion, there is a need to align information disclosure tendencies to the needs of shareholders and stakeholders. A proposed means to solve this is to include internal and external monitoring mechanisms to ensure that efficient disclosure takes place.

Useful in understanding discretionary disclosure difficulties are the agency and signalling theories. These theories both suggest that firms are motivated to disclose the excellence of their financial performance in an unambiguous manner. Connelly, Certo, Ireland and Reutzel (2011, p. 40) describe the signalling theory as useful in describing behavior when two parties have different information to present. In cases where the sender (the company) chooses what to communicate, for example, in the chairperson's statement, the sender may select what to communicate and what not, whereas the sender is more regulated in the financial statements to present statements that are truly reflective of a company's 
current standing. The agency theory is concerned with resolving two problems that can occur in agency relationships. The first agency problem that may arise is when the goals of the principal and agent conflict, and the second is when it becomes difficult for the principal to verify what the agent is actually doing (Eisenhardt, 1989, p. 58). The cornerstone of the agency theory is the assumption that, at some point, the interests of the principal and agent are divergent (Hill \& Jones, 1992, p. 132).

Allegrini and Greco (2013, p. 191) explain that corporate governance and voluntary disclosures are two mechanisms that are used to protect investors and reduce the agency problem. Concealment of information may be done so as to not alarm stakeholders about the operations and strategy of the organization. Concealment can arise when the organization anticipates negative outcomes for the organization (Abrahamson \& Park, 1994, p. 1304). This creates conflict of interest, because corporate managers may not want negative organizational outcomes revealed, whereas shareholders may view this concealed information as important in making an informed decision about whether or not to keep their shares.

Even though the demand for financial reporting and disclosure arises from information asymmetry and agency conflicts between the company and external investors, Healy and Palepu (2001, p. 412) acknowledge regulatory disclosure yet question which disclosure should be left to the discretion of management and which should not. This is based on the assumption that managers of organizations have more information on the future performance of the company than external investors, and that if regulation is skewed managers will trade off their superior knowledge to manage reported performance for political and corporate governance reasons.

Ingram (1983, pp. 50-51) suggests that voluntary disclosures should be associated with the company's performance, as revealed in the financial statements, and should also be linked with the following environmental factors:

- The political environment: Potential constraints as a result of the social visibility of the firm, as well as economic importance of the company.

- The agency relationship: Differences that may exist between owners and management of the firm, as well as the level of control management can exert on the company.

- The regulatory environment: Constraints imposed by the legal constraints of a country.

- Contractual agreements: Potential constraints imposed by labor bodies, vendors and creditors of a firm.
The signalling theory and agency theory are used together to determine the determinants of corporate reporting. This is often done, as the combination of these two theories can provide a better prediction of a company's accounting reporting choices.

2.4. Stakeholder theory. There are a variety of stakeholder groups to whom the company managers are also responsible (Yuthas, Rogers \& Dillard, 2002, p. 142). Stakeholders may be defined as "any group or individual who can affect or is affected by the achievement of the organization's objectives" (Freeman in Hutt, 2010, p. 182). A company's stakeholders may include primary and secondary groups such as competitors, suppliers, employees, consumer advocate groups, communities and the government (Hutt, 2010, p. 182). Older research described the chairperson's statement as a tool designed for public consumption, often with the intent to present the company in the most favorable light, not only to the financial world, but also to other stakeholders (Gowler \& Legge, 1993, p. 48).

More recently, engagement practices have risen to a new level of importance and are seen as a critical way to inform and gain feedback on a company's employed strategy (Hutt, 2010, p. 182). Yuthas et al. (2002) affirm that an active engagement with stakeholders can, thus, be considered both a condition for and a consequence of the stakeholder approach to corporate governance.

However, Yuthas et al. (2002) add that despite the important theoretical debate about stakeholder engagement, little empirical research on the benefits of stakeholder relationships exists.

2.5. Legitimacy theory. The legitimacy theory considers the expectations stakeholders have of organizations. The basic premise of the legitimacy theory is that companies can maintain their operations to the extent that the community perceives the company to be meeting its expectations (Deegan, 2014, p. 253). Mathews (1993, p. 350) defines legitimacy as organizations seeking to establish congruence between the social values associated with or implied by their activities and the norms of acceptable behavior in the larger social system of which they are a part. At organizational level, legitimacy is important for companies, as it helps to ensure the continued inflow of capital, labor and customers necessary for viability (Tilling, 2004). This means that companies should manage their legitimacy, as it helps to stall negative actions against the company and gives the company some level of autonomy regarding how they conduct their business. However, Tilling (2004) warns against the use of the abstract measure of legitimacy, stating that instead of subjective measures of legitimacy by researchers, legitimacy 
can be inferred from the 'fact' that legitimate organizations are able to attract resources for their survival. Legitimacy, however, still provides a foundation in explaining corporate disclosures of companies. Organizations in their communication with stakeholders may establish, maintain and, in both negative and positive circumstances, defend their legitimacy.

\section{Research methodology}

The sample for this study consisted of 50 topperforming companies on the JSE main board, as well as 50 poor-performing companies. These companies were selected using Earnings Before Interest, Taxes, Depreciation and Amortisation (EBITDA) to rank them as either high-performing or poor-performing. EBITDA provided a fair means to compare companies across industries, since it does not take into account financing and accounting decisions. This was necessary in this particular study. A limitation of EBITDA, however, is that it does not measure cashflow which can be misleading to an extent.

This list of 100 companies was obtained from the McGregor BFANet database. The integrated annual reports of these companies for the 2012 financial year were downloaded from the companies' corporate websites. Companies ranged from mining companies to pharmaceutical companies, hotel groups, banking companies, real estate companies, transport and freight companies, and medical groups.

The units of analysis, that is, the chairperson's statements of the various companies, are contained within the integrated annual reports. Furthermore, the chairperson's statement was converted to Rich Text Format (RTF) to allow optimal analysis of the document using the Atlas.ti software package. Atlas.ti software allowed the researchers to create codes, and from these codes group similar or related codes into code families, which were then interpreted as the reactive or proactive discretionary disclosures in the chairperson's statement. The purpose of coding is to capture meaning in data and to create a set of related information units for the purpose of comparison (Atlas.ti 7, 2013, p. 16). The study did not aim to bring any company into disrepute and, therefore, anonymity of the companies is maintained in the discussion of the findings.

For the purpose of this research, the inductive approach to content analysis was used, as the study aimed to understand how the formulation of the chairperson's statement takes place and to determine the perspective from which it is written.

Figure 1 below depicts the data production and data analysis process followed in the research.

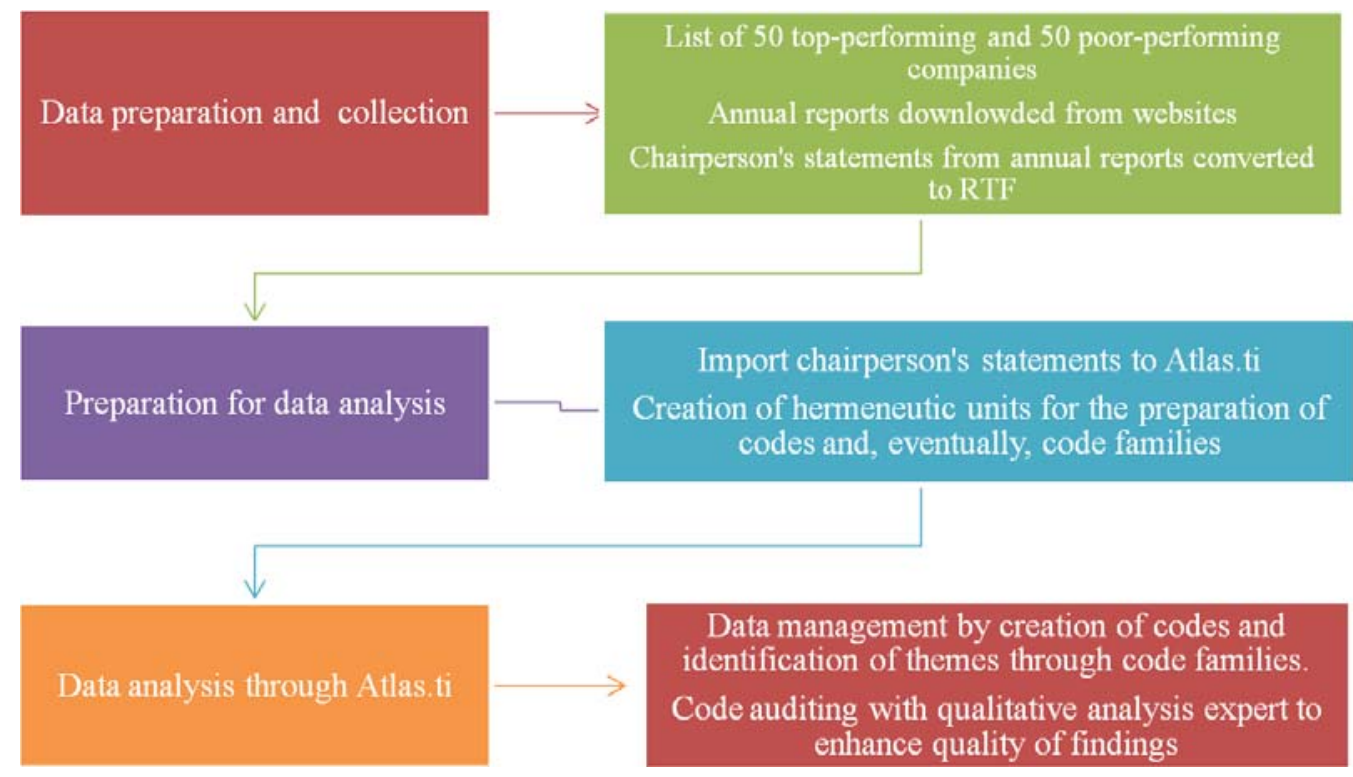

Fig. 1. Research implementation process

Source: author's own compilation.

\section{Findings and results}

The discussions in this section explain the stance of the chairpersons of high- and poor-performing companies in communicating plans, projects, proposals and initiatives, and the overall strategic direction of the company. Reactivity was judged on whether the chairpersons detailed efforts and plans as a response to external factors, and proactivity was judged on whether the chairpersons communicated efforts and plans that fed into the company's strategic direction and included a dimension of growth.

4.1. Contextual review. Two dynamics dominated the press for the period under review and had a direct impact on the South African economy, thus, affecting 
the operational environment in which South African companies operated (South African Reserve Bank, 2012, p. 8; Oxford Business Group, 2013). The two factors that dominated reporting in South African media during the 2012 period were:

- the global financial crisis of 2009 ;

- the Marikana miners' massacre.

4.1.1. The global financial crisis of 2009. In 2009, world markets were largely affected by what is known to be the biggest recession since the Great Depression of 1929 (Crotty, 2009, p. 563; Frenkel \& Rapetti, 2009, p. 685; Carmassi, Gros \& Micossi, 2009, p. 977). The cause of this global financial crisis was attributed to the housing bubble in the United States of America in which potential homeowners were granted loans under what are today deemed poor lending practices (Obstfeld \& Rogoff, 2009).

A high-performing company explains the performance environment against which the company fared, an opinion that could be marked similar to that of poorperforming companies:

The 2012 financial year has been characterized by challenging market conditions from a global macroeconomic and local perspective. The global economy continued to experience the effects of the financial downturn, and recovery has taken longer than anticipated, particularly in Europe and the United States (High-performing company 50).

Statements like the one above could often be found in the beginning of the chairperson's statement, a move that could be interpreted as managing stakeholder expectations and a major point of reference in explaining the company's performance throughout the chairperson's statement. It should, however, be noted that high-performing companies often used this as a means to show how they still achieved good results despite a difficult macro-economic environment that had many adverse effects on many sectors:

These achievements are especially pleasing considering the tough economic climate in 2012; a difficult year for many exploration companies both locally and internationally (High-performing company 18).

While it is believed that companies in developing countries were not as harshly affected, the effect of this global financial crisis had, to some extent, an impact on the performance of companies. In 2012, both highperforming and poor-performing companies still mentioned the effects of this crisis on their performance. In this sense, both were reacting to influences in the macro environment.

4.1.2. The Marikana miners' massacre. On 16 August 2012, the events that took place at the Lonmin Platinum Belt at Marikana in the North
West Province of South Africa left 34 miners dead and 78 others wounded (Alexander, Lekgowa, Mmope, Sinwell, \& Xeswi, 2013; Satgar, 2012). While the causes of this massacre are layered around eroded labor relations, unfair wages paid to miners, the inability of government to implement the Mining Charter and power struggles between unions (Twala, 2012; Botiveau, 2014), this event garnered interest in the annual reports of companies published after this period.

Despite the fact that the mining sector has experienced great decline in its contribution to the economy of South Africa, from $21 \%$ in 1970 , to $6 \%$ in 2011, mining remains a key sector in the economy of South Africa in terms of foreign exchange earnings, employment and economic activity (Statistics South Africa, 2012). Companies directly involved in the mining sector acknowledged the events at Marikana as tragic, but called on the government to put fairer policies in place, which are realistic requirements by unions, as the mining sector is a key sector in the country's economy. One chairperson of a mining company expresses this view in the following quote:

The Marikana tragedy and its aftermath crystallized in the most shocking way the complex challenges we face in creating a healthy and sustainable society. A sombre and self-critical response to the absence of stewardship at all levels that predicated the terrible events at Marikana is entirely appropriate, for ultimately we will be judged as a nation by what we learn from what happened, and what we do with those lessons (High-performing company 26).

Mining companies featured prominently in the list of high-performing companies for this study (11 out of 50). Other than reporting on improved safety performance through a decline in reported fatalities at the mines, reactions in their chairperson's statements were centred around issues with greater political concern such as nationalization, corruption in the government tendering processes or the excessive taxing of mining companies; which mining companies believed negatively affected investment opportunities in the sector. Such high-performing mining companies make a great contribution to the country's tax.

4.2. Formalization of reporting standards. The formalization of reporting requirements, such as corporate governance, environmental disclosures and sector-specific issues, has made the discussion of certain pertinent issues necessary for inclusion in the chairperson's statement. From the chairperson's perspective, the inclusion of these issues in the chairperson's statement may be seen as a display of a sincere effort at accountability. From the reader's perspective, the inclusion of such issues may be seen as a way to judge the legitimacy of the organization. Despite guidance available for listed companies on 
what to include in the annual report, with the 2012 annual report being either the company's first or second integrated annual report, a lot of confusion existed about the content and format of the annual report (South African Institute of Chartered Accountants, 2012). While companies committed themselves to adhering to King III requirements, as stipulated in the JSE requirements, listed companies also acknowledged challenges encountered in compiling these integrated annual reports. This is highlighted in the following quote:

The challenge remains to ensure that we are able to integrate sustainability into our business strategy and practice. We continue to focus on developing a framework for sustainable development, ensuring compliance with the key requirements of regulations such as the King III Code, the Listings Requirements of the JSE Limited and the Companies Act of 2008. The board strives to provide strong leadership, strategic direction and a productive environment that can sustain the delivery of value to our shareholders and other stakeholders (Highperforming company 21).

The chairperson's statement, as a customary component of the annual report, may not be considered the correct platform to discuss details regarding all aspects of adherence to the recommendations of the King III guide to corporate governance. However, these aspects of corporate governance were pertinent in the annual report of the 2012 financial year.

Depending on the issue at hand and its importance for the reputation of the company, the chairperson's statement is formulated reactively to meet the desires of the potential audience, and proactively from the perspective of the chairperson in covering what he or she deems necessary for the audience to know, without tainting the organization's image, all the while maintaining legitimacy and displaying accountability.

4.3. Competitive advantage. Communicating competitive advantage in the chairperson's statement could also be linked to signalling theory. It was important to demonstrate this element, as it highlighted how the company would create value in the short, medium and long term. A company's ability to achieve its targets, and in addition to refer to its clean record of accomplishment, were signals for the company's competitive advantage. This is highlighted in the quote below:

In April of this year, [company name withheld] received a remarkable accolade. The Reputation Institute surveyed a broad base of South African respondents about their view of the reputation of South Africa's 20 most reputable companies. On every single criteria, [company name withheld] came first - the company is the most admired brand in South Africa (High-performing company 43).

Share price is an important measure of company performance. Simply stated, share price is the stock price of the company and can be seen as representative of the future flows of the company (Willcocks, 2010, p. 63). For investors, the value of the share price is important, as it provides a good indication of return on investment. In the difficult operating environment experienced by companies, irrespective of whether high-performing or poorperforming, the ability to maintain solid, positive cash flows is something the investor may consider attractive and a competitive advantage.

The inclusion of financial information such as dividends in the chairperson's statement is a major highlight and signal for the investor. This is if mandatory guidelines for truthful, honest and accurate guidelines of the Company's Act of 2011 are adhered to. The declaration of such financial information must be done honestly, because failure to provide truthful and verifiable information may be to the detriment of the organization. Despite the fact that the chairperson's statement is an unaudited disclosure, the inclusion of information pertaining to dividends can be seen as binding to the organization, as such promises have to be fulfilled.

4.4. The company as a going concern. Barkemeyer, Comyns, Figge and Napolitano $(2014$, p. 1) state that annual reports are an important form of communication between a company and its internal and external stakeholders. The importance of these reports stems from the need to communicate nonfinancial issues. They further argue that corporate sustainability reporting could be deemed successful if legitimacy was maintained, regardless of the quality or accuracy of the report.

High-performing companies and poor-performing companies reported differently in this regard. However, both high-performing and poor-performing companies alike remained vague in the chairperson's statements about how they communicated their sustainability efforts. It was more evident in poorperforming companies that no stable guarantees were available that the company would still be in existence in the two- to three-year period to follow. Much of this came from their discussion of their strategy and how capital within the company would be sufficient until the next financial year and that the company needed more financial injection.

Cash at year-end amounted to $\$ 180$ million which should be sufficient to manage our business for the coming year. Opportunities for raising finance are kept under constant review (Poor-performing company 1 ). 
As an unaudited disclosure statement, the prescription by regulation, The King Code of Corporate Governance and the JSE make it hard for companies to conceal any material information. These reactive legislative prescriptions and listing requirements have made companies proactive in their disclosure. As much as the chairperson and the board are the ultimate decision-makers of what goes into the chairperson's statement, scandals such as Enron, Fidentia, Masterbond and many more have made it hard for companies to conceal information pertaining to the company as a going concern. The company's performance was the major determinant in whether the company formulated the chairperson's statement reactively or proactively.

4.5. Responsiveness to the societal contract. Socially responsive companies were aware of the environment/society within which they operated. Even though this is subtly prescriptive in order to operate in today's society, 'voluntary' integration into society is essential in the legitimacy of the organization. More so in South Africa, where corporate social responsibility disclosures are interesting to consider due to the country's long period of apartheid which resulted in unequal economic and social wealth distribution for the black majority of citizens (Ntim \& Soobaroyen, 2013, p. 121). High-performing companies would commonly indicate the rand amount of their spend on corporate social responsibility. Table 1 highlights the differences in reporting corporate social responsibility (CSR) between a high-performing and poorperforming company is highlighted below:

Table1. Differences in reporting on CSR between high-performing and poor-performing companies

\begin{tabular}{|l|l|l|}
\hline $\begin{array}{c}\text { CSR } \\
\text { within the } \\
\text { listed } \\
\text { company }\end{array}$ & \multicolumn{1}{|c|}{ High-performing companies } & Poor-performing companies \\
\hline \multirow{1}{*}{} & $\begin{array}{l}\text { (Company name omitted) } \\
\text { committed R22.7 million during } \\
\text { the year to CSI initiatives with the } \\
\text { aim of making positive, lasting } \\
\text { impacts in the communities in } \\
\text { which we operate. With a key } \\
\text { focus on education and skills } \\
\text { development, our overarching } \\
\text { aim is to develop and empower } \\
\text { people so that they can gainfully } \\
\text { contribute to economic growth } \\
\text { (High-performing company 6). }\end{array}$ & $\begin{array}{l}\text { In line with King III and global } \\
\text { trends, this integrated annual } \\
\text { report was prepared to offer a } \\
\text { concise commentary on } \\
\text { (Company name omitted) } \\
\text { economic, social and } \\
\text { environmental performance } \\
\text { during this period, within the } \\
\text { broader context of macro- } \\
\text { economic and market } \\
\text { realities (Poor-performing } \\
\text { company 35). }\end{array}$ \\
$\begin{array}{l}\text { (Company name omitted) has } \\
\text { over the past three years, spent } \\
\text { approximately R300 million on } \\
\text { various projects which resulted } \\
\text { in the provision or improvement } \\
\text { of health, education, water, } \\
\text { roads, electricity and other } \\
\text { facilities to the communities } \\
\text { living near our mines and } \\
\text { elsewhere in the country (High- } \\
\text { performing company 2). }\end{array}$ & $\begin{array}{l}\text { Social responsibility initiatives } \\
\text { are aimed at empowering } \\
\text { communities through } \\
\text { education, health, housing, } \\
\text { community and supply chain } \\
\text { initiatives. In 2012 the budget } \\
\text { was severely reduced due to } \\
\text { cash-flow restrictions as a } \\
\text { result of the loss the } \\
\text { Company made (Poor- } \\
\text { performing company 6). }\end{array}$ \\
\hline
\end{tabular}

\section{Conclusions and recommendations}

Previous studies (Abrahamson \& Park, 1994; Bournois \& Point, 2006; Stanton \& Stanton, 2002) suggest that most chairpersons attributed good performance to hands-on, well thought-out strategy and sound guidance provided by the board of directors. From this perspective, chairpersons presented their companies as proactive in their performance and the achievement of financial success. Reactivity in this research was based on responsiveness to the economic climate and whether the company was responsive to factors related to the company's performance.

The formalization of reporting standards contributed towards the reactiveness of companies. Formalization of reporting standards in the requirement set out by the JSE that all annual reports become integrated reports, led to the underlying misconception that these standards were prescriptive in nature instead of providing guidance on strategy, risk, performance and sustainability being inseparable.

While the effects of the global financial crisis of 2009 were evident in the performance of both highperforming and poor-performing companies, overall reactivity or proactivity could be determined based on the issue at hand. From the perspective of the chairperson, issues in the macro environment and, to a certain extent, issues in the company's market environment were reactively responded to. Issues pertaining to the company's direct environment were often described proactively in the plans, projects and goals of the company.

The chairperson's statements that were analyzed were often downward forms of communication and none of the listed companies provided any opportunity for feedback or clarification on any of the matters discussed. It was never made clear by the listed companies if any forums existed for feedback or input by stakeholders into the annual report. This is recommended even if for a limited time after the publication of that specific annual report.

It is also recommended that future research be directed towards the analysis of industry-specific chairperson's statements. The chairperson's statements of companies in sectors ranging from pharmaceutical companies, mining, construction, telecommunication, hospitality, healthcare and banking, to retail and manufacturing, were analyzed in this research. In the dichotomous sample of highperforming and poor-performing companies, companies could be classified into various and often similar industries. It would be worthwhile to understand formulation perspectives and differences in the chairperson's statements of companies in similar sectors. 


\section{References}

1. Abrahamson, E. and Amir, E. (1996). The information content of the president's letter to shareholders, Journal of Business Finance and Accounting, 23 (8), pp. 1157-1182.

2. Abrahamson, E. and Park, C. (1994). Concealment of negative organisational outcomes: An agency theory perspective, Academy of Management Journal, 37 (5), pp. 1302-1334.

3. Allegrini, M. and Greco, G. (2013). Corporate boards, audit committees and voluntary disclosure: Evidence from Italian listed companies, Journal of Management \& Governance, 17 (1), pp. 187-216.

4. Alexander, P., Lekgowa, T., Mmope, B., Sinwell, L. and Xeswi, B. (2013). Marikana: A view from the mountain and a case to answer. South Africa: Jacana Media.

5. Andreasson, S. (2009). Understanding corporate governance reform in South Africa: Anglo-American divergence, the King reports and hybridization, Business \& Society, 50 (4), pp. 647-673.

6. Atlas.ti. (2013). Atlas.ti 7: user guide and reference. Available at: http://www.atlasti.com/uploads/media/atlasti_v7_manual_201312.pdf. Accessed on 2014-01-05.

7. Barkemeyer, R., Comyns, B., Figge, F. and Napolitano, G. (2014). CEO statements in sustainability reports: Substantive information or background noise? Accounting Forum, 38 (4), pp. 241-257.

8. Beattie, V., McInnes, B. and Fearnley, S. (2004). A methodology for analysing and evaluating narratives in annual reports: A comprehensive descriptive profile and metrics for disclosure quality attributes, Accounting Forum, 28 (3), pp. 205-236.

9. Bebbington, J., Unerman, J. and O'Dwyer, B. (eds). (2014). Sustainability Accounting and Accountability. Abingdon: Routledge.

10. Bournois, F. and Point, S. (2006). A letter from the president: Seduction, charm and obfuscation in French CEO letters, Journal of Business Strategy, 27 (6), pp. 46-55.

11. Botiveau, R. (2014). Briefing: The politics of Marikana and South Africa's Changing labor relations, African Affairs, 113 (450), pp. 128-137.

12. Carmassi, J., Gros, D. and Micossi, S. (2009). The global financial crisis: Causes and cures, Journal of Common Market Studies, 47 (5), pp. 977-996.

13. Cheng, C.M. and Courtenay, S.M. (2006). Board composition, regulatory regime and voluntary disclosure, The International Journal of Accounting, 41, pp. 262-289.

14. Connelly, B.L., Certo, S.T., Ireland, R.D. and Reutzel, C.R. (2011). Signalling theory: a review and assessment, Journal of Management, 37 (1), pp. 39-67.

15. Crotty, J. (2009). Structural causes of the global financial crisis: a critical assessment of the "new financial architecture', Cambridge Journal of Economics, 33 (4), pp. 563-580.

16. Deegan, C. (2014). An overview of legitimacy theory as applied within the social and environmental accounting literature. In: Bebbington, J, Unerman J and O'Dwyer, B (eds.), Sustainability Accounting and Accountability. New York: Routledge, pp. 248-272.

17. Depoers, F. (2000). A cost benefit study of voluntary disclosure: Some empirical evidence from French listed companies, European Accounting Review, 9 (2), pp. 245-263.

18. Eisenhardt, K.M. (1989). Agency theory: An assessment and review, The Academy of Management Review, 14 (1), pp. $57-74$.

19. Frenkel, R., and Rapetti, M. (2009). A developing country view of the current global crisis: What should not be forgotten and what should be done, Cambridge Journal of Economics, 33 (4), pp. 685-702.

20. Gowler, D. and Legge, K. (1993). Images of employees in annual reports: Do company chairperson view their most valuable assets as valuable? Personnel Review, 20 (3), pp. 41-54.

21. Healy, P.M. and Palepu, K.G. (2001). Information asymmetry, corporate disclosure and the capital markets: A review of empirical disclosure literature, Journal of Accounting and Economics, 31, pp. 405-440.

22. Hill, C.W.L. and Jones, T.M. (1992). Stakeholder-Agency Theory, Journal of Management Studies, 29 (2), pp. $131-154$.

23. Hutt, R.W. (2010). Identifying and mapping stakeholders: An industry case, Corporate Communications: An International Journal, 15 (2), pp. 181-191.

24. Ingram, R.W. (1983). Narrative disclosures in annual reports, Journal of Business Research, 11, pp. 49-60.

25. Institute of Directors Southern Africa. (2009). King Code of Governance of South Africa 2009. Available at: http://www.library.up.ac.za/law/docs/King_Code_2009.pdf. Accessed on 2 February 2013.

26. Ioannou, I. and Serafeim, G. (2016). The consequences of mandatory corporate sustainability reporting: evidence from four countries. Harvard Business School Research Working Paper No. 11-100.

27. Kohut, G.F. and Segars, A.H. (1992). The president's letter to stockholders: An examination of the corporate communication strategy, The Journal of Business Communication, 29 (1), pp. 7-21.

28. Leventis, S. and Weetman, P. (2004). Impression management: Dual language reporting and voluntary disclosure, Accounting Forum, 28, pp. 307-328.

29. Mangena, M. and Chamisa, E. (2008). Corporate governance and incidences of listing suspension by the JSE Securities Exchange of South Africa: An empirical analysis, The International Journal of Accounting, 43 (1), pp. 28-44.

30. Mathews, M.R. (1993). Socially responsible accounting. London: Chapman \& Hall.

31. Merkl-Davies, D.M. and Brennan, N.M. (2007). Discretionary disclosure strategies in corporate narratives: Incremental information or impression management? Journal of Accounting Literature, 26, pp. 116-194. 
32. Myburgh, J.E. (2001). The informativeness of voluntary disclosure in the annual reports of listed industrial companies in South Africa, Meditari Accountancy Research, 9, pp. 199-216.

33. Ntim, C.G. and Soobaroyen, T. (2013). Black economic empowerment disclosures by South African listed corporations: The influence of ownership and board characteristics, Journal of Business Ethics, 116, pp. 121-138.

34. Obstfeld, M. and Rogoff, K.S. (2009). Global imbalances and the financial crisis: products of common causes. London: Centre for Economic Policy Research.

35. Oxford Business Group. (2013). South Africa: Year in Review 2012. Available at: http://www.oxfordbusinessgroup.com/economic_updates/south-africa-year-review-2012. Accessed on 2014-07-30.

36. Padia, N. \& Yasseen, Y. (2011). An examination of strategy disclosure in the annual reports of South African listed companies, South African Journal of Business Management, 42 (3), pp. 27-35.

37. Riley, T.J. and Luippold, B.L. (2015). Managing Investors' Perception Through Strategic Word Choices In Financial Narratives, Journal of Corporate Accounting \& Finance, 26 (5), pp. 57-62.

38. Satgar, V. (2012). Beyond Marikana: The post-apartheid South African state, African Spectrum, 47 (2-3), pp. 33-62.

39. Smith, M. and Taffler, R.J. (2000). The chairperson's statement: A content analysis of discretionary narrative disclosure, Accounting, Auditing \& Accountability Journal, 13 (5), pp. 624-646.

40. Solomon, J. and Maroun, W. (2012). Integrated reporting: the influence of King III on social, ethical and environmental reporting integrated reporting in SA. Available at: http://www.accaglobal.com/content/dam/acca/global/PDFtechnical/integrated-reporting/tech-tp-iirsa.pdf. Accessed on 2012-11-20.

41. South African Institute of Chartered Accountants (SAICA). (2012). Significant changes in the way in which JSE listed companies report. Available at: https://www.saica.co.za/News/NewsArticlesandPressmediareleases/ tabid/695/itemid/3694/language/en-US/Default.aspx. Accessed on 2015-05-15.

42. South African Reserve Bank (SARB). (2012). The impact of the Eurozone financial crisis on African economies. Available at: https://www.resbank.co.za/AnalyticsReports/Nepad\%20Business\%20Forum\%20-\%20Final\%20 Version\%20-\%2017\%20April\%202012.pdf. Accessed on 2015-06-30.

43. Stanton, P. and Stanton, J. (2002). Corporate annual reports: Research perspectives used, Accounting, Auditing \& Accountability Journal, 15 (4), pp. 478-500.

44. Statistics South Africa. (2012). Mining: production and sales (Preliminary). Statistical release P2041. 13 March 2014. Available at: http://beta2.statssa.gov.za/publications/P2041/P2041March2014.pdf. Accessed on 2014-07-20.

45. Stocken, P.C. (2012). Discussion of 'interactive discretionary disclosure', Contemporary Accounting Research, 29 (2), pp. 398-402.

46. Tilling, M.V. (2004). Refinements to legitimacy theory in social and environmental accounting. Adelaide: School of Commerce, Flinders University.

47. Twala, C. (2012). The Marikana massacre: a historical overview of the labor unrest in the mining sector in South Africa, Southern African Peace and Security Studies, 1 (2), pp. 61-67.

48. Verrecchia, R.E. (1983). Discretionary disclosure, Journal of Accounting and Economics, 5, pp. 179-194.

49. West, A. (2009). The ethics of corporate governance: A (South) African perspective, International Journal of Law and Management, 51 (1), pp. 10-16.

50. Willcocks, L. (2010). The next step for the CEO: Moving IT-enabled services outsourcing to the strategic agenda, Strategic Outsourcing: An International Journal, 3 (1), pp. 62-66.

51. Yeoh, P. (2010). Narrative reporting: the UK experience, International Journal of Law and Management, 52 (3), pp. 211-231.

52. Yuthas, K., Rogers, R. and Dillard, J.F. (2002). Communicative action and corporate annual reports, Journal of Business Ethics, 41, pp. 141-157. 